\title{
Alcanivorax pacificus sp. nov., isolated from a deep-sea pyrene-degrading consortium
}

Correspondence
Zongze Shao
shaozz@163.com

The genus Alcanivorax, a group of marine hydrocarbondegrading bacteria, is recognized as part of the obligate hydrocarbonoclastic bacteria (OHCB) due to the capacity of its members to utilize a variety of hydrocarbons. Since the genus was first proposed by Yakimov et al. (1998), $>250$ Alcanivorax-affiliated bacteria, based on 16S rRNA gene sequences, have been isolated or detected in various types of marine environment, such as surface, shallow and deep seawater, sediments and hydrothermal vents, and even a few terrestrial environments (Yakimov et al., 2007). At the time of writing, the genus Alcanivorax comprised six recognized species, A. borkumensis (Yakimov et al., 1998), A. jadensis (Bruns \& Berthe-Corti, 1999), A. venustensis (Fernández-Martínez et al., 2003), A. dieselolei (Liu \& Shao, 2005a), A. balearicus (Rivas et al., 2007) and A. hongdengensis (Wu et al., 2009), all of which were isolated from marine environments except $A$. balearicus, which was isolated from a subterraneous saline lake in Mallorca,

†These authors contributed equally to this work.

Abbreviation: $\mathrm{OHCB}$, obligate hydrocarbonoclastic bacteria.

The GenBank/EMBL/DDBJ accession numbers for the 16S rRNA, partial gyrB and partial alkB gene sequences of strain $W 11-5^{\top}$ are DQ659451, GU395984 and GU395983, respectively.

Four supplementary figures and two supplementary tables are available with the online version of this paper.
Spain. In this study, we describe a novel strain, designated $\mathrm{W} 11-5^{\mathrm{T}}$, which was isolated from a pyrene-degrading consortium enriched from a deep-sea sediment sample collected from the western Pacific Ocean (Wang et al., 2008). Three novel species have, so far, been isolated from this pyrene-degrading consortium and described: Roseovarius pacificus (Wang et al., 2009), Oceanicola pacificus (Yuan et al., 2009) and Bowmanella pacifica (Lai et al., 2009). The type strains of these three species, along with strain $\mathrm{W} 11-5^{\mathrm{T}}$, were, however, unable to degrade pyrene. Strain $\mathrm{W} 11-5^{\mathrm{T}}$ was characterized and classified by using a polyphasic approach and was found to be phylogenetically related to members of the genus Alcanivorax. Routine cultivation of the strain and most of the phenotypic tests were carried out on $216 \mathrm{~L}$ marine agar medium (MAM), comprising ( $\mathrm{g} \mathrm{l}^{-1}$ seawater) $\mathrm{CH}_{3} \mathrm{COONa}$ (1), tryptone (10), yeast extract (2), sodium citrate (0.5), $\mathrm{NH}_{4} \mathrm{NO}_{3}$ (0.2) (pH 7.5), according to (Yuan et al., 2009) unless stated otherwise.

Genomic DNA was prepared according to the method of Ausubel et al. (1995) and the 16S rRNA gene was amplified by PCR using primers that have been described previously (Liu \& Shao, 2005a). 16S rRNA gene sequences of related taxa were obtained from the GenBank database. Phylogenetic analysis was performed using MEGA version 4 (Tamura et al., 2007) after multiple sequence alignment 
using DNAMAN version 5.1 (Lynnon Biosoft). Distances (distance options according to the Kimura two-parameter model; Kimura, 1980) and clustering with the neighbourjoining (Saitou \& Nei, 1987) and minimum-evolution (Rzhetsky \& Nei, 1992, 1993) methods were determined by using bootstrap support based on 1000 replications.

The nearly full-length 16S rRNA gene sequence (1506 nt) of strain W11-5 ${ }^{\mathrm{T}}$ was determined. Phylogenetic analysis of strain $\mathrm{W} 11-5^{\mathrm{T}}$ indicated that it was a member of the class Gammaproteobacteria, forming a robust clade within the genus Alcanivorax (Fig. 1 and Supplementary Fig. S1, available in IJSEM Online). The closest related neighbours to strain $\mathrm{W} 11-5^{\mathrm{T}}$ were $A$. dieselolei $\mathrm{B}-5^{\mathrm{T}}, A$. balearicus MACL $04^{\mathrm{T}}$, A. hongdengensis A-11- $3^{\mathrm{T}}$, A. venustensis $\mathrm{ISO} 4^{\mathrm{T}}$, A. borkumensis $\mathrm{SK}^{\mathrm{T}}$ and A. jadensis $\mathrm{T}^{\mathrm{T}}$ with $16 \mathrm{~S}$ rRNA gene sequence similarities of $93.9,93.1,93.1,93.0,93.0$ and $92.9 \%$, respectively; type strains of other species shared $<92 \%$ sequence similarity with strain $\mathrm{W} 11-5^{\mathrm{T}}$. As a $16 \mathrm{~S}$ rRNA gene sequence divergence greater than $3 \%$ is generally accepted as the recommended criterion for the delineation of bacterial species (Stackebrandt \& Goebel, 1994), these similarity values supported the view that strain $\mathrm{W} 11-5^{\mathrm{T}}$ represented a novel species of the genus Alcanivorax.

A $1058 \mathrm{nt}$ fragment of the housekeeping gene $\operatorname{gyrB}$ (encoding DNA gyrase subunit B) was obtained from strain $\mathrm{W} 11-5^{\mathrm{T}}$ by using the method described by Yamamoto et al. (2000) and showed sequence similarities of $80.8,80.7,78.9,77.8,76.9$ and $76.8 \%$ to $A$. venustensis $\mathrm{ISO}^{\mathrm{T}}{ }^{\mathrm{T}}$ A. hongdengensis $\mathrm{A}-11-3^{\mathrm{T}}$, A. jadensis $\mathrm{T}^{\mathrm{T}}$, A. dieselolei $\mathrm{B}-5^{\mathrm{T}}, A$. borkumensis $\mathrm{SK}^{\mathrm{T}}$ and $A$. balearicus MACL $04^{\mathrm{T}}$, respectively. This indicated that strain W11-5 satisfied the recommended threshold criterion (10\% nucleotide substitution rate; Venkateswaran et al., 1999) of sequence diversity to distinguish it as a novel species. The phylogenetic tree based on gyrB gene sequences (Supplementary Fig. S2) showed that strain W11-5 formed an independent monophyletic cluster with other species of the genus Alcanivorax, which was similar to that seen in the tree based on $16 \mathrm{~S}$ rRNA gene sequences.

A $549 \mathrm{nt}$ fragment of the alkane hydroxylase gene alkB was amplified from strain $\mathrm{W} 11-5^{\mathrm{T}}$ by PCR using previously described primers (Wang et al., 2010) and alignment of deduced amino acid sequences showed that strain W11- $5^{\mathrm{T}}$ had the highest similarity to $A$. venustensis $\mathrm{ISO}^{\mathrm{T}}$ (82.5\%). Based on amino acid sequences deduced from the alkB gene, strain $\mathrm{W} 11-5^{\mathrm{T}}$ clustered with $A$. dieselolei $\mathrm{B}-5^{\mathrm{T}}$, A. balearicus MACL04 $4^{\mathrm{T}}$ and $A$. venustensis $\mathrm{ISO}^{\mathrm{T}}$ (Supplementary Fig. S3), forming a separate group with similarities of 78.7-82.5\%; however, compared to phylogenetic positions based on 16S rRNA gene sequences, there was no clear grouping of species, as previously described by Van Beilen et al. (2003). For example, A. dieselolei $\mathrm{B}-5^{\mathrm{T}}$ and A. borkumensis $\mathrm{SK} 2^{\mathrm{T}}$ contain multiple alkB gene sequences, therefore, phylogenetic analysis of their deduced amino acid sequences placed them on completely different branches, unlike analyses based on 16S rRNA and gyrB gene sequences (Supplementary Fig. S1 and S2).

Cell morphology was determined under an Olympus inverted microscope using two-day-old cultures of strain W11-5 $5^{\mathrm{T}}$ grown on 216L MAM according to (Yuan et al., 2009). For electron microscopy, exponential-phase cells were harvested, suspended and subsequently absorbed on to a Formvar-carbon-coated grid followed by staining with phosphotungstic acid (Supplementary Fig. S4). Gramstaining and activities of catalase, oxidase, amylase and gelatinase were determined according to standard methods (Dong \& Cai, 2001). The optimal temperature for growth was determined by growth at $4-45{ }^{\circ} \mathrm{C}$ on $216 \mathrm{~L}$ MAM. Tolerance of $\mathrm{NaCl}$ was determined by using 216L MAM, with seawater replaced by distilled water, supplemented with $0,0.5,1,3,5,7,10,12,15,17$ and $20 \%(\mathrm{w} / \mathrm{v}) \mathrm{NaCl}$. Utilization of $n$-alkanes as carbon sources was determined by growing cells of strain $\mathrm{W} 11-5^{\mathrm{T}}$ in $0.1 \%(\mathrm{w} / \mathrm{v})$ ASM medium as described by Liu \& Shao (2005b) with chainlengths ranging from $\mathrm{C}_{10}$ to $\mathrm{C}_{36}$. Other biochemical tests were carried out by using API 20 NE and API ZYM test kits (bioMérieux) and a Biolog GN2 MicroPlate panel, according to the manufacturer's instructions but with the media adjusted to contain $3 \%(\mathrm{w} / \mathrm{v}) \mathrm{NaCl}$, the results of which are given in the species description and in Table 1.

The DNA G $+\mathrm{C}$ content of strain $\mathrm{W} 11-5^{\mathrm{T}}$ was determined using reversed-phase HPLC according to the methods described by Mesbah \& Whitman (1989). The DNA G+C content of strain $\mathrm{W} 11-5^{\mathrm{T}}$ was $60.8 \mathrm{~mol} \%$, which was within the range previously reported for species of the genus Alcanivorax (53.4-66.4 mol\%; Table 1).

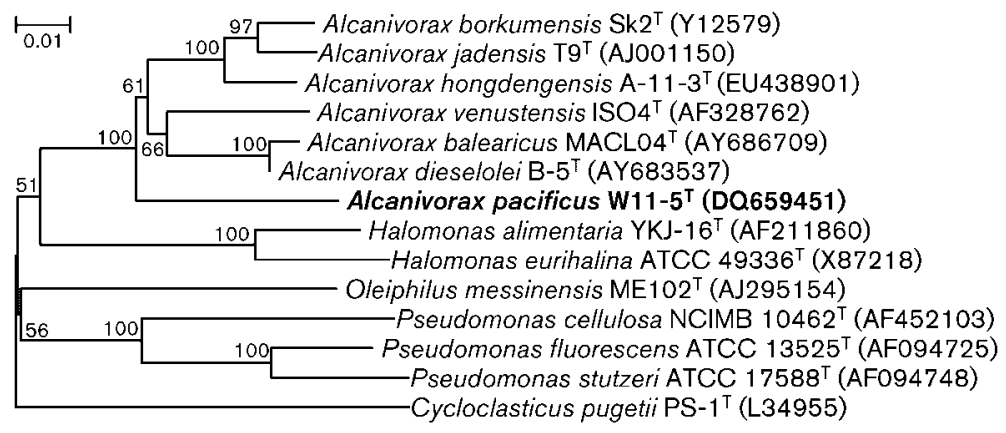

http://ijs.sgmjournals.org
Fig. 1. Neighbour-joining tree based on $16 \mathrm{~S}$ rRNA gene sequences showing the phylogenetic position of strain $\mathrm{W} 11-5^{\top}$ with those of type strains of closely related taxa. Bootstrap values $>50 \%$ (based on 1000 replications) are shown at branch points. Bar, 0.01 substitutions per nucleotide position ( $\left.K_{\text {nuc }}\right)$. 
Table 1. Characteristics of strain $\mathrm{W} 11-5^{\top}$ and closely related members of the genus Alcanivorax

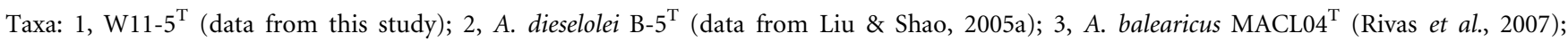
4, A. hongdengensis A-11-3 ${ }^{\mathrm{T}}$ (Wu et al., 2009); 5, A. venustensis ISO4 ${ }^{\mathrm{T}}$ (Fernández-Martínez et al., 2003); 6, A. borkumensis SK2 ${ }^{\mathrm{T}}$ (Yakimov et al., 1998); 7, A. jadensis T9 ${ }^{\mathrm{T}}$ (Bruns \& Berthe-Corti, 1999; Fernández-Martínez et al., 2003). Tests for catalase and oxidase activities and tests in the API $20 \mathrm{NE}$ and API ZYM systems were performed in parallel for all seven type strains. In the API 20 NE system, all strains were negative for denitrification, indole production, arginine dihydrolase and $\beta$-galactosidase activities and for the utilization of D-mannose, D-mannitol, maltose and potassium gluconate. In the API ZYM system, all strains were positive for esterase (C4), esterase lipase (C8), lipase (C14), leucine aminopeptidase, weakly positive for valine aminopeptidase and negative for cystine aminopeptidase, $N$-acetyl- $\beta$-glucosaminidase, trypsin, $\alpha$-chymotrypsin, $\alpha$-fucosidase, $\alpha$ - and $\beta$-galactosidase, $\alpha$-glucosidase, $\alpha$-mannosidase and $\beta$-glucuronidase. + , Positive; w, weakly positive; - , negative.

\begin{tabular}{|c|c|c|c|c|c|c|c|}
\hline Characteristic & 1 & 2 & 3 & 4 & 5 & 6 & 7 \\
\hline Catalase & + & + & + & - & + & + & - \\
\hline Oxidase & + & $\mathrm{w}$ & $\mathrm{W}$ & - & + & $\mathrm{W}$ & + \\
\hline Motility, flagella arrangement & - & $+^{*}$ & $+\dagger$ & - & $+^{*}$ & - & - \\
\hline Ionic requirements & $\mathrm{Na}^{+}$ & $\mathrm{Na}^{+}$ & - & $\mathrm{Na}^{+}$ & Complex & Complex & $\mathrm{Na}^{+}$ \\
\hline Growth in $17 \% \mathrm{NaCl}$ & - & w & - & - & + & - & - \\
\hline Growth at $42{ }^{\circ} \mathrm{C}$ & + & + & - & + & + & - & + \\
\hline Growth at $45{ }^{\circ} \mathrm{C}$ & - & + & - & - & + & - & + \\
\hline DNA G $+\mathrm{C}$ content $(\mathrm{mol} \%)$ & 60.8 & 62.1 & 62.8 & 54.7 & 66.4 & 53.4 & 63.6 \\
\hline \multicolumn{8}{|l|}{ API 20 NE: } \\
\hline Nitrate reduction & + & - & $\mathrm{w}$ & + & - & - & - \\
\hline D-Glucose fermentation & $\mathrm{w}$ & - & - & - & - & - & - \\
\hline $\begin{array}{l}\text { Urease, } \beta \text {-glucosidase, } \\
\text { D-glucose, L-arabinose, } \\
N \text {-acetylglucosamine }\end{array}$ & + & - & - & - & - & - & - \\
\hline Gelatin hydrolysis & - & - & - & + & - & + & - \\
\hline Capric acid, phenylacetic acid & - & + & + & - & - & - & - \\
\hline Adipic acid & $\mathrm{w}$ & + & + & - & + & - & - \\
\hline Malic acid & + & + & - & - & - & - & - \\
\hline Trisodium citrate & - & + & + & - & - & - & - \\
\hline \multicolumn{8}{|l|}{ API ZYM: } \\
\hline $\begin{array}{l}\text { Acid phosphatase, } \\
\text { naphthol-AS-B1-phosphoamidase }\end{array}$ & $\mathrm{w}$ & + & + & $\mathrm{W}$ & + & + & + \\
\hline Alkaline phosphatase & $\mathrm{w}$ & + & + & - & $\mathrm{w}$ & + & + \\
\hline$\beta$-Glucosidase & + & - & - & - & - & - & - \\
\hline
\end{tabular}

${ }^{\star}$ Lophotrichous flagella.

$\dagger$ Polar or subpolar flagellum.

Antibiotic susceptibility tests were performed according to Lai et al. (2009) by using the disc diffusion method with Oxoid discs. Strain $\mathrm{W} 11-5^{\mathrm{T}}$ and the six type strains of species of the genus Alcanivorax were tested in parallel. All the strains were sensitive to ( $\mu$ g per disc unless otherwise indicated) polymyxin B (30) but resistant to clindamycin (2), furazolidone (15), lincomycin (2), metronidazole (5), oxacillin (1) and vancomycin (30). The sensitivity of the seven strains to 23 other kinds of antibiotics was also determined (Supplementary Table S1).

Fatty acids of cells grown aerobically on Marine Agar (BD) supplemented with $1.0 \mathrm{~g} \mathrm{CH}_{3} \mathrm{COONa} \mathrm{l}^{-1}$ and $0.5 \mathrm{~g}$ trisodium citrate $1^{-1}(\mathrm{pH} 7.5)$ at $28{ }^{\circ} \mathrm{C}$ for $72 \mathrm{~h}$ were extracted, saponified and esterified and the fatty acid methyl esters were analyzed by GC according to the instructions of the MIDI system (Sasser, 1990). The fatty acids profiles of the six type strains of species of the genus Alcanivorax were also determined by using the same method with cells grown under the same conditions. As shown in Supplementary Table S2, the predominant fatty acids of all seven type strains were $\mathrm{C}_{16: 0}, \mathrm{C}_{18: 1} \omega 7 c$ and summed feature $3\left(\mathrm{C}_{16: 1} \omega 6 c\right.$ and/or $\left.\mathrm{C}_{16: 1} \omega 7 c\right)$, which accounted for $\sim 47-76 \%$ of the total fatty acids. In addition, strain $\mathrm{W} 11-5^{\mathrm{T}}$ contained summed feature 9 (iso- $\mathrm{C}_{17: 1} \omega 9 c$ and/or $\mathrm{C}_{16: 0} 10$-methyl) (9\%), which was absent in the other strains.

As shown in Table 1, there are some significant characteristics that distinguish strain $\mathrm{W} 11-5^{\mathrm{T}}$ from closely related species of the genus Alcanivorax. Therefore, on the basis of its morphological, physiological and chemotaxonomic characteristics, together with the results of phylogenetic analyses based on the $16 \mathrm{~S}$ rRNA and gyrB gene 
sequences, strain $\mathrm{W} 11-5^{\mathrm{T}}$ represents a novel species of the genus Alcanivorax, for which the name Alcanivorax pacificus sp. nov. is proposed.

\section{Description of Alcanivorax pacificus sp. nov.}

Alcanivorax pacificus (pa.ci'fic.us. L. masc. adj. pacificus pacific, pertaining to the Pacific Ocean).

Cells are Gram-reaction-negative, short non-motile rods, $1.7-2.3 \mu \mathrm{m} \times 0.3 \mu \mathrm{m}$. Oxidase- and catalase-positive. Positive for nitrate reduction, urease and $\beta$-glucosidase activities and D-glucose fermentation (weakly) but negative for indole production, denitrification and gelatinase, $\beta$-galactosidase and arginine dihydrolase activities. Produces smooth, grey-white, non-pigmented colonies with regular edges that are $1-2 \mathrm{~mm}$ in diameter and slightly raised in the centre after $72 \mathrm{~h}$ incubation at $28{ }^{\circ} \mathrm{C}$ on 216L MAM. Moderately halophilic. Grows in $0.5-12 \%$ (w/v) $\mathrm{NaCl}$ (optimum 3-5\%) and at $10-42{ }^{\circ} \mathrm{C}$ (optimum $25-28{ }^{\circ} \mathrm{C}$ ) but not at $4{ }^{\circ} \mathrm{C}$ or $45{ }^{\circ} \mathrm{C}$ within a week. The principal fatty acids were $\mathrm{C}_{12: 0} 3-\mathrm{OH}, \mathrm{C}_{16: 0}, \mathrm{C}_{18: 1} \omega 7 c$, summed feature $3\left(\mathrm{C}_{16: 1} \omega 6 c\right.$ and/or $\left.\mathrm{C}_{16: 1} \omega 7 c\right)$ and summed feature 9 (iso- $\mathrm{C}_{17: 1} \omega 9 c$ and/or $\mathrm{C}_{16: 0} 10$-methyl). In the API ZYM system, tests are positive for esterase (C4), esterase lipase (C8), leucine aminopeptidase, $\beta$-glucosidase and lipase (C14) activities, weakly positive for acid phosphatase, alkaline phosphatase, naphthol-AS-B1-phosphoamidase and valine aminopeptidase activities and negative for cystine aminopeptidase, $N$-acetyl- $\beta$-glucosaminidase, trypsin, $\alpha$-chymotrypsin, $\alpha$-fucosidase, $\alpha$ - and $\beta$-galactosidase, $\alpha$-glucosidase, $\alpha$-mannosidase and $\beta$-glucuronidase activities. In the API $20 \mathrm{NE}$ system, tests are positive for utilization of adipic acid (weakly), D-glucose, L-arabinose, malic acid and $\mathrm{N}$-acetylglucosamine but negative for utilization of capric acid, maltose, D-mannitol, D-mannose, phenylacetic acid, potassium gluconate and trisodium citrate. Among the 95 carbon sources in the Biolog system (GN2 plate), tests are positive for utilization of Tweens 40 and 80 , L-arabinose and methyl pyruvate and weakly positive for utilization of propionic acid. Sensitive to ( $\mu \mathrm{g}$ per disc unless otherwise indicated) kanamycin (30), minomycin (30), ciprofloxacin (5), rifampicin (5), chloromycetin (30) and polymyxin B (30 IU) but resistant to ampicillin (10), carbenicillin (100), cefalexin (30), cefazolin (30), Cefobid (30), cephradin (30), clindamycin (2), Cotrimoxazole (25), erythromycin (15), furazolidone (15), gentamicin (10), lincomycin (2), metronidazole (5), neomycin (10), norfloxacin (10), ofloxacin (5), oxacillin (1), penicillin $G$ (10), piperacillin (100), rocephin (30), streptomycin (10), tetracycline (30), vancomycin (30) and vibramycin (30). Grows well in ASM with $n$-alkane as a carbon source with chain-lengths from $\mathrm{C}_{14}$ to $\mathrm{C}_{28}$.

The type strain, W11-5 ${ }^{\mathrm{T}}\left(=\right.$ MCCC $1 \mathrm{~A} 00474^{\mathrm{T}}=$ CCTCC AB $208236^{\mathrm{T}}=$ LMG $25514^{\mathrm{T}}$ ), was isolated from sediment of the Pacific Ocean. The DNA G + C content of the type strain is $60.8 \mathrm{~mol} \%$.

\section{Acknowledgements}

This work was financially supported by the National Science Foundation of China (40906083), the China Ocean Mineral Resources R\&D Association Program (no. DYXM115-02-2-05), the National Infrastructure of Natural Resources for Science and Technology Program of China (no. 2005DKA21209) and the Scientific Research Foundation of Third Institute of Oceanography, SOA (no. 2009065). We thank Dr Raúl Rivas, Dr Peter N. Golyshin, Dr Alke Bruns and Dr Jesús García-Martínez for kindly providing the type strains A. balearicus MACL04 ${ }^{\mathrm{T}}$, A. borkumensis $\mathrm{SK} 2^{\mathrm{T}}$, A. jadensis $\mathrm{T} 9^{\mathrm{T}}$ and $A$. venustensis $\mathrm{ISO}^{\mathrm{T}}{ }^{\mathrm{T}}$, repectively.

\section{References}

Ausubel, F. M., Brent, R., Kingston, R. E., Moore, D. D., Seidman, J. G., Smith, J. A. \& Struhl, K. (editors) (1995). Short Protocols in Molecular Biology: a Compendium of Methods from Current Protocols in Molecular Biology, 3rd edn. New York: Wiley.

Bruns, A. \& Berthe-Corti, L. (1999). Fundibacter jadensis gen. nov., sp. nov., a new slightly halophilic bacterium, isolated from intertidal sediment. Int J Syst Bacteriol 49, 441-448.

Dong, X.-Z. \& Cai, M.-Y. (2001). Determinative Manual for Routine Bacteriology. Beijing: Scientific Press (English translation).

Fernández-Martínez, J., Pujalte, M. J., García-Martínez, J., Mata, M., Garay, E. \& Rodríguez-Valeral, F. (2003). Description of Alcanivorax venustensis sp. nov. and reclassification of Fundibacter jadensis DSM $12178^{\mathrm{T}}$ (Bruns and Berthe-Corti 1999) as Alcanivorax jadensis comb. nov., members of the emended genus Alcanivorax. Int J Syst Evol Microbiol 53, 331-338.

Kimura, M. (1980). A simple method for estimating evolutionary rates of base substitutions through comparative studies of nucleotide sequences. J Mol Evol 16, 111-120.

Lai, Q., Yuan, J., Wang, B., Sun, F., Qiao, N., Zheng, T. \& Shao, Z. (2009). Bowmanella pacifica sp. nov., isolated from a pyrenedegrading consortium. Int J Syst Evol Microbiol 59, 1579-1582.

Liu, C. \& Shao, Z. (2005a). Alcanivorax dieselolei sp. nov., a novel alkane-degrading bacterium isolated from sea water and deep-sea sediment. Int J Syst Evol Microbiol 55, 1181-1186.

Liu, C. \& Shao, Z. (2005b). Isolation and characterization of oildegrading marine micro-organisms. Acta Oceanol Sin 27, 114-120.

Mesbah, M. \& Whitman, W. B. (1989). Measurement of deoxyguanosine/thymidine ratios in complex mixtures by high-performance liquid chromatography for determination of the mole percentage guanine + cytosine of DNA. J Chromatogr A 479, 297-306.

Rivas, R., Garcia-Fraile, P., Peix, A., Mateos, P. F., Martínez-Molina, E. \& Velázquez, E. (2007). Alcanivorax balearicus sp. nov., isolated from Lake Martel. Int J Syst Evol Microbiol 57, 1331-1335.

Rzhetsky, A. \& Nei, M. (1992). A simple method for estimating and testing minimum evolution trees. Mol Biol Evol 9, 945-967.

Rzhetsky, A. \& Nei, M. (1993). Theoretical foundation of the minimum-evolution method of phylogenetic inference. Mol Biol Evol 10, 1073-1095.

Saitou, N. \& Nei, M. (1987). The neighbor-joining method: a new method for reconstructing phylogenetic trees. Mol Biol Evol 4, 406425.

Sasser, M. (1990). Identification of bacteria by gas chromatography of cellular fatty acids, MIDI Technical Note 101. Newark, DE: MIDI Inc.

Stackebrandt, E. \& Goebel, B. M. (1994). Taxonomic note: a place for DNA-DNA reassociation and $16 \mathrm{~S}$ rRNA sequence analysis in the present species definition in bacteriology. Int J Syst Bacteriol 44, 846-849. 
Tamura, K., Dudley, J., Nei, M. \& Kumar, S. (2007). MEGA4: molecular evolutionary genetics analysis (MEGA) software version 4.0. Mol Biol Evol 24, 1596-1599.

Van Beilen, J. B., Li, Z., Duetz, W. A., Smits, T. H. M. \& Witholt, B. (2003). Diversity of alkane hydroxylase systems in the environment. Oil Gas Sci Technol 58, 427-440.

Venkateswaran, K., Moser, D. P., Dollhopf, M. E., Lies, D. P., Saffarini, D. A., MacGregor, B. J., Ringelberg, D. B., White, D. C., Nishijima, M. \& other authors (1999). Polyphasic taxonomy of the genus Shewanella and description of Shewanella oneidensis sp. nov. Int J Syst Bacteriol 49, 705-724.

Wang, B., Lai, Q., Cui, Z., Tan, T. \& Shao, Z. (2008). A pyrene-degrading consortium from deep-sea sediment of the West Pacific and its key member Cycloclasticus sp. P1. Environ Microbiol 10, 1948-1963.

Wang, B., Tan, T. \& Shao, Z. (2009). Roseovarius pacificus sp. nov., isolated from deep-sea sediment. Int J Syst Evol Microbiol 59, 1116-1121.

Wang, L., Wang, W., Lai, Q. \& Shao, Z. (2010). Gene diversity of CYP153A and AlkB alkane hydroxylases in oil-degrading bacteria isolated from the Atlantic Ocean. Environ Microbiol 12, 1230-1242.
Wu, Y., Lai, Q., Zhou, Z., Qiao, N., Liu, C. \& Shao, Z. (2009). Alcanivorax hongdengensis sp. nov., an alkane-degrading bacterium isolated from surface seawater of the straits of Malacca and Singapore, producing a lipopeptide as its biosurfactant. Int J Syst Evol Microbiol 59, 1474-1479.

Yakimov, M. M., Golyshin, P. N., Lang, S., Moore, E. R. B., Abraham, W. R., Lünsdorf, H. \& Timmis, K. N. (1998). Alcanivorax borkumensis gen. nov., sp. nov., a new, hydrocarbon-degrading and surfactant-producing marine bacterium. Int J Syst Bacteriol 48, 339-348.

Yakimov, M. M., Timmis, K. N. \& Golyshin, P. N. (2007). Obligate oildegrading marine bacteria. Curr Opin Biotechnol 18, 257-266.

Yamamoto, S., Kasai, H., Arnold, D. L., Jackson, R. W., Vivian, A. \& Harayama, S. (2000). Phylogeny of the genus Pseudomonas: intrageneric structure reconstructed from the nucleotide sequences of gyrB and rpoD genes. Microbiology 146, 2385-2394.

Yuan, J., Lai, Q., Wang, B., Sun, F., Liu, X., Du, Y., Li, G., Gu, L., Zheng, T. \& Shao, Z. (2009). Oceanicola pacificus sp. nov., isolated from a deepsea pyrene-degrading consortium. Int J Syst Evol Microbiol 59, 11581161. 